\title{
Siyasal Kültür: Yeni Yaklaşımlara Genel Bir Bakış
}

\author{
Köksal ÇALIŞKAN ${ }^{*}$
}

\section{Öz}

Siyasal kültür bir kuram olarak, Gabriel A. Almond ve Sidney Verba’nın 1963 yılında yayınladıkları "The Civic Culture" çalışması ile ortaya çıkmıştı. Ancak "The Civic Culture", yayınlandıktan sonra büyük eleştiriler topladı. Bu eleştiriler, bir taraftan siyasal kültür kuramının sorgulanmasına yol açarlarken, diğer taraftan ise, siyasal kültürü yeniden tanımlamaya yönelik çalışmaların itici gücü oldular. Sonuçta, “The Civic Culture” yanında, ortaya birçok yeni yaklaşım çıktı. Bu yaklaşımlar Birgit Schwelling tarafından "Tutumlar odaklı", "Sembol odaklı" ve "Bilgi odaklı yaklaşımlar” olmak üzere üç kategoride toplanmışlardı. Bu makalenin amacı, bu 3 kategoride toplanan yaklaşımların kapsamlı bir değerlendirmesini yaparak, siyasal kültür araştırmalarının günümüzde geldiği düzeyi göstermektir.

Anahtar kelimeler: Siyasal kültür teorileri, Lowell Dittmer, Aaron Wildavsky, Karl Rohe, Birgit Schwelling.

\section{Political Culture: An Overview of the New Approaches}

\begin{abstract}
The theory of Political Culture originates from the work "The Civic Culture" by Gabriel A. Almond and Sidney Verba published in 1963. However, after being published, "The Civic Culture" was harshly criticized. This criticism, on the one hand, has caused the questioning of the theory of political culture and, on the other hand, has become a moving force to redefine the concept of political culture. As a result, along with "The Civic Culture" approach, many other different approaches have emerged. Among these approaches, Birgit Schwelling distinguishes three categories: "Attitudes-oriented", "Symboloriented" and "Knowledge-oriented". The aim of this article is to make a comprehensive evaluation of new approaches to the Civic Culture which are summarized under these three categories and to indicate the level of contemporary researches on political culture.
\end{abstract}

Keywords: The Theories of Political Culture, Aaron Wildavsky, Lowell Dittmer, Karl Rohe, Birgit Schwelling.

* Yrd. Doç. Dr. Karabük Üniversitesi, İktisadi ve İdari Bilimler Fakültesi, Siyaset Bilimi ve Kamu Yönetimi Bölümü, Demir Çelik Kampüsü, 78050 Karabük. 


\section{Giriş}

Siyasal kültür; bir kuram olarak Gabriel A. Almond ve Sidney Verba’nın Amerika Birleşik Devletleri, İngiltere, Almanya, İtalya ve Meksika'yı kapsayan çalışmaları olan “The Civic Culture” çalışmasının 1963 yılında yayınlanması ile siyaset bilimine giriş yaptı. Kuram, yayınlanmasının akabinde büyük bir ilgi uyandırarak, siyasal değişim ve gelişim modellerinin vazgeçilmez açıklayıcılarından biri haline geldi. Ancak çalışmanın yayınlanmasını takip eden yıllar, aynı zamanda bu ilginin giderek sönümlenmesine yol açacak gelişmelerin yaşandığı yıllar oldular. Özellikle iki gelişme, siyasal kültür kuramının sorgulanmasına ve başlangıçtaki önemini kaybetmesine yol açtılar. Bunlardan ilki, siyaset bilimi içerisinde "Bağımlılık Teorisi" ve "Rasyonel Seçim Teorisi” gibi teorilerin ağırlık kazanmaya ve böylece siyasal kültür odaklı analizlerin önemlerini yavaş yavaş kaybetmeye başlamalarıdı (Pye, 1991a:505). Diğer gelişme ise, The Civic Culture çalışmasının büyük eleştiriler toplamasıydı.

Bu eleştiriler içerisinde özellikle iki noktaya değinmekte fayda var. İlk olarak, The Civic Culture, siyasal kültürü tanımlarken analiz düzeyi olarak bireyi temel almıştı. ${ }^{1}$ Buna göre, belirli bir anket ya da mülakata katılan bireylerin siyasete ilişkin algı, değer ve tutumları toplamının bir ülkedeki siyasal kültür tipini ortaya çıkaracağı düşünülmüştü (Almond ve Verba, 1963:14-15, 31-76). Böylelikle The Civic Culture, bireysel tutumlardan toplumsal olana ulaşma hedefi üzerine inşa edilmişti. Fakat çalışmanın dayandığı bu temel birçok eleştiri toplamıştı (Scheuch, 1993a; 1993b; 2006; Verba, 1993; Lijphart, 1989). Bir defa Emile Durkheim (1982:54), The Civic Culture çalışmasından yaklaşık yarım yüzyıl önce, inanış, eğilim ve pratiklerin kolektif olduğunu ve bunun bireylerin sahip oldukları inanışlardan, eğilimlerden ve pratiklerden farklı olduğunu, bu kolektif olgunun bireylerin davranışlarının toplamıyla bulunamayacağını belirtmişti. Diğer taraftan The Civic Culture çalışmasının dayandı̆̆ı bu temel, bireyin toplumdan soyutlanarak ele alınmasına yol açmıştı. Fakat birey içerisinde yaşadığı grup -toplum ya da topluluk- ile beraber anlaşılabilirdi (Latham, 1952:376-377; Brady ve Sniderman, 1985:1061; Newcomb, 1942). Örneğin Maurice Halbwachs'a göre (1939:812-815), birey, toplumdan ayrı görüldüğü zaman bile kendi dışında oluşan kolektif bir psikolojinin etkisi altındaydı.

Çalışmanın bireye odaklanması aslında siyasal kültür tanımının dayandırıldığı kültür tanımıyla ilgili bir durumdu. Almond ve Verba (1963:14), büyük ölçüde Talcott Parsons’in tezlerinden etkilenerek, kültürü, "sosyal objelere yönelik psikolojik yönelimler (psychological orientations)" olarak tanımlamışlardı. Ancak kültür, Parsons’’n teorisinde özel bir anlama sahipti. Swidler’a göre (1986:274), Parsons'in teorisinde aktör, toplumsal bir durumda seçimler yapan olarak tasvir edilmekteydi ve değerlerin görevi de neden farklı aktörlerin benzer durumlarda farklı seçimler yaptıklarını açıklamaktı. Kültür burada hem sosyal sistemin devamını sağlayacak bir öğe, hem de insani yapının bir parçası olarak görülmüştü, çünkü Parsons’a göre her türlü eylem bir araçamaç şeması ${ }^{2}$ (means-ends schema) tarafından yönetiliyordu ve kültür de seçim yapmak için

1 Siyasal kültür, The Civic Culture içerisinde; "the particular distribution of patterns of orientation toward political objects among the members of the nation” (Almond ve Verba 1963: 14-15) olarak tanımlamıştı. 
alternatif oryantasyonlara temel olacak şekilde değer oryantasyonları sunmaktaydı (Swidler, 1986:273-274). Swidler’a göre (1986:274), kültür ile davranış arasındaki bu ilişki, Parsons tarafından Weber'in ilgiler ve değerler üzerine olan düşüncelerinden türetilmiş olmakla beraber yapısal işlevselcilik tarafından tamamen yanlış okunmuştu. ${ }^{3}$ Öte yandan The Civic Culture içerisinde kültür, parçalarının birleştirilmesiyle oluşturulmuş bir toplama denk gelen, "birleşik bir bütün” olarak düşünülmüştü (Almond ve Verba, 1963:10-14; Almond, 1989:12-24). Oysa kültür; parçalarının toplamından daha fazlasını içermekteydi (Benedict, 1960:54; Kluckhohn ve Hoebel, 1943:222-226).

İkinci olarak The Civic Culture, siyasal kültür ile siyasal yapı arasındaki etkileşimi göz ardı ederek, siyasal kültürü siyasal yapının belirleyicisi olarak gördügüne yönelik olarak eleştirilmişti (Pateman, 1971; Muller ve Seligson, 1994; Gendzel, 1997). Bundan dolayı, Almond ve Verba daha sonra yaptıkları çalışmalarda, siyasal kültür ile siyasal yapı arasındaki ilişkiyi, karşılıklı etkileşim temelinde yeniden tanımlamaya çalışmışlardı (Almond, 1987; 1989; Verba, 1965).

Çalışmaya ve dolayısıyla da siyasal kültür kuramına getirilen bu eleştirilerin sonuçlarından biri, yukarıda belirtildiği gibi, kuramın geçerliliğinin sorgulanması ve bundan dolayı siyasal kültüre olan ilginin sönmeye başlaması olmuştu. Ancak bu durum fazla uzun sürmedi; 1970'li yıllardan itibaren kültür ile siyaset arasındaki etkileşim sosyal bilimlerde yeniden merak konusu olmaya ve bu çerçevede kültür, siyasal geri kalmışlığın nedenlerinden biri olarak gösterilmeye başlandı. $\mathrm{Bu}$ gelişme, siyasal kültür kavramına olan eleştirileri sona erdirmemesine rağmen, onun bir "Rönesans" (Inglehart, 1988; Pye, 1991a) yaşamasıyla sonuçlandı.

Öte yandan bu eleştiriler, tüm bu süreçlere eşlik eden başka bir sürecin, siyasal kültürü tanımlamaya yönelik çalışmaların, hem itici gücü hem de temel şekillendiricisi oldular. Bu eleştiriler karşısında bir kısım çalışmalar, küçük rötuşlar yaparak The Civic Culture geleneğini devam ettirmeye yöneldiler. Ancak bu çalışmalar, ne yukarıdaki eleştirilere tatmin edici bir cevap sunabildiler ne de siyasal kültürün bir kuram olarak yerleşmesini beraberinde getirdiler. Bu yüzden diğer birçok çalışma ise, The Civic Culture tarafından sunulan çerçevenin dışına çıkarak, bireyin dışında var olan, bireyin siyasete ilişkin tutum, duygu, düşünce, değer ve algılarının şekillenmesine etki eden faktörleri temel alarak bu eleştirilere bir cevap sunmaya çalıştılar. Bu çabaların en önemli sonucu ise, ortaya birçok yeni yaklaşımın çıkması oldu (Berezin, 1997; Chilton, 1988; Formisano, 2001; Jowitt, 1974; Somers, 1992; Wilson, 2000). Glenda M. Patrick (1984:271-280), bu yaklaşımları şu şekilde sınıflandırmıştı;

1) "Easton tarafından yapılmış olan "nesnel” (Objective) kavramsallaştırılma,

2) Almond ve Verba ile Almond ve Powell tarafindan yapılan "psikolojik" ya da "öznel" (Subjective) kavramsallaştırma,

3 The Civic Culture ile hemen aynı dönemde yayınlanmış ve değerler ile ilgileri ele alan bir çalışma için ayrıca bkz. (Dyke, 1962). 
3) Pye tarafindan yapılan "bulgusal" (Heuristic) kavramsallaștırma,

4) Fagen ve Tucker tarafindan yapılan "içlemsel" (Comprehensive) kavramsallaştırma".

Fakat hemen belirtilmelidir ki, hem siyasal kültürü tanımlamaya yönelik yaklaşımların sayısı burada belirtilenlerden oldukça fazla, hem de yapılan bu tür sınıflandırmalar kullanılan perspektife göre değişiklik gösterebiliyorlar. Örneğin Oscar W. Gabriele göre (1994:25), siyasal kültürü tanımlamaya yönelik hemen hemen tüm yaklaşımlar "heuristic" çatısı altında birleștirilebilirler. Bu problemi gidermenin yollarından biri, yaklaşımları, analiz düzeylerini temel alarak sinıflandırmak olabilir. Böyle bir sinıflandırma Birgit Schwelling (2001) tarafından yapılmıştı. Schwelling'in sınıflandırmasının ilk ayağını, The Civic Culture ve onu model olarak alan çalışmaları içeren "Tutumlar odakl yaklaşımlar" oluşturmaktaydı. Schwelling, siyasal kültürü tanımlamaya yönelik diğer yaklaşımları ise iki kategoride toplamıştı: "Sembol odaklı yaklaşımlar" ve "Bilgi odakl yaklaşımlar".

$\mathrm{Bu}$ makalenin amacı, bu üç kategoride toplanan yaklaşımlardan belli başlı olanların kapsamlı bir değerlendirmesini yaparak, siyasal kültür araştırmalarının günümüzde ulaştığı düzeyi göstermektir.

\section{Tutumlar Odaklı Yaklaşımlar}

Tutumlar odaklı yaklaşımların başlıca kaynağı, siyasal kültürü, bireylerde siyasete ilişkin tutumların bir toplamı olarak gören The Civic Culture (Almond ve Verba, 1963) çalışmasıydı. Ancak The Civic Culture bir başka makalede detaylı bir şekilde değerlendirildiği için, ne kendisi ne de onun bu geleneğini küçük makyajlarla devam ettiren Ronald Inglehart (1971; 1988; 1996a; 1996b) ile Robert D. Putnam (1966; 1971; Putnam vd., 1993) gibi önemli isimlerin tezleri, burada ele alınmayacaklar. Bu yüzden, burada, bu çatı altında yer alan, ancak siyasal kültürü tutumların bir toplamından ziyade onu tercihler düzeyinde tanımlayan iki ismin tezlerine yer verilmesi uygun görüldü; Aaron Wildavsky ve Virginie D. Mamadouh. ${ }^{6}$

\section{Aaron Wildavsky}

$\mathrm{Bu}$ yaklaşımın önemli referans noktalarından bir tanesi Mary Douglas tarafından ortaya atılan ve Michael Thompson, Richard J. Ellis ve Aaron Wildavsky tarafından geliștirilen Kültürel Teori'dir (Cultural Theory).? Kültürel Teori, Douglas'ın “Grid-Group" hipotezine dayanıyor. " "Grid- Group"

4 Pye tarafından siyasal kültüre ilişkin çalışmalardan bazıları için bkz. (Pye, 1978; 1991b).

5 Örneğin bkz. (Tucker, 1973).

6 Aslında Schwelling tarafından yapılan sınıflandırmada Wildavsky ve Mamadouh herhangi bir kategori içerisinde yer almıyordu. Bu makalede tercihlerin, mikro düzeyde oluşacağı düşünülerek, bu çatı altında ele alınmaları uygun görüldü.

7 Kültürel Teori için ayrıca bkz. (Swedlow, 2011; Lockhart, 2001; Bergesen, 1978; Hendriks, 1999; Dake ve Thompson, 1999).

8 "Grid-Group" için ayrıca bkz. (Douglas, 1972; 1989; 1999). 
teorisi ise, Spickard’a göre (1989:151), Douglas'ın Durkheim'in sosyal faktörlerin inanışları, indirgemeci olmadan nasıl koşullandırdığı sorusunu yeniden canlandırmasına dayanıyor. Burada sosyal gerçekliğin bilinci inşa etme şekli kadar gerçekliğin kendisinin sosyal inşa edilme şekli de önemli, çünkü belirli “sosyal ayarlar” (social settings) dünyayı görmenin belirli şekillerini desteklemekteler. Spickard’a göre (1989:151), “Grid-Group” teorisi de, bu bağlantıyı açıklamayı ve öngörmeyi mümkün kılmak için tasarlanmıştı. Ancak, yine Spickard’a göre (1989:152), Douglas bu teoriyi geliştirmede tutarlı değildi, çünkü yazılarında 3 ayrı “Grid-Group” teorisi öne sürmüştü.

Douglas (1989:411), Spickard’a cevaben “Grid-Group” teorisinin tutumlar, değerler ve “GridGroup” pozisyonlarıyla bağlantılı olarak yerleşmiş düşünce kalıpları üzerine soru sormak ve cevaplamak için tasarlandığını belirtmiş, ancak onun 3 farklı teori sunulduğuna ilişkin tespitlerine ise katılmak durumunda kalmıştı. Bununla beraber, bir başka makalesinde Douglas, “Grid-Group” teorisini, kültürel “bias” temelinde açıklamıştı. Douglas’a göre (1999:411), kültürel “bias", her biri bir diğerine göre tanımlanmış, her biri kendini, kendi tanımının aktiviteleri yoluyla devam ettirilebilen, her zaman potansiyel olarak her insan grubunda var olan ve birbirlerine karşı savaş halindeki 4 ayrı gruba ayrılıyordu. Burada kültürel "bias”, bir kurumsal şeklin gruplarından biri ya da diğeri için sabit bir tercih ve bunun bir sonucu olarak onunla giden bilgi çeşidine bir bağlılık anlamına geliyordu (Douglas, 1999:411). Douglas (1999:411), bu yüzden tüm kültürel çatışmaların, organizasyonun şekli üzerine olduğunu iddia etmişti. Bu 4 gruptan her biri, kültürel temellerin aşınmasına tahammül edemeyeceği, stabil organizasyonun bir tipine dayanıyordu. Bir başka ifade ile, bu 4 grup aynı zamanda 4 ayrı organizasyon şekline dayanıyordu ve geri kalan karışımlar ise geçiş sürecindekiler olarak kabul ediliyorlardı (Douglas, 1999:411).

\section{Kültür Haritası (Douglas, 1999:4I2)}

$\mathrm{B}=$ tecrit edilenler, seçerek veya zorla, kompleks yapılar içerisinde sözün gerçek anlamıyla yalnız ve ya dışlanmış

$A=$ rekabetçi bireycilik, zayıf yapı, zayıf birliktelik
$\mathrm{C}=$ hiyerarşiler, kompleks yapılar ile birlikte kaynaşmış gruplar

$\mathrm{D}=$ eşitlikçi dışa kapalı bölge veya cemaatler zayıf yapılar ile birlikte kaynaşmış gruplar

Douglas (1999:412), buradaki kültürel “bias” tiplerini ise şöyle açılamıştı:

1) A bireyselcilik ile uyum sağlıyor, gelenek ile uyuşmuyor, organizasyon şekli liyakata açı ve rekabetçi.

2) B yönetmeyi ya da takip etmeyi, ikna etmeyi ya da organize etmeyi ümit etmeyen ve amaçlamayan herkesi kapsayan bir sisteme denk geliyor.

3) C gelenek ve düzeni destekliyor, hiyerarşik organizasyon şekli ile uyuşuyor.

4) D kapalı ve eşitlikçi bir sisteme denk geliyor. 
Temel tezleri böyle özetlenmeye çalışılan Kültürel Teori, siyasal kültürü tanımlanmak isteyenler için önemli esin kaynaklarından birini oluşturdu. Kültürel Teoriyi temel alarak siyasal kültürü tanımlamaya çalışanların başında Aaron Wildavsky geliyor. ${ }^{9}$ Wildavsky (1987), siyasal kültürü, tutumların bir toplamı düzeyinden, kültür temelli tercihler düzeyine çekerek orada tanımlamaya çalışmıştı. Çünkü Wildavsky’ye göre (1987:3), siyasal tercihlerin araştırılması, sadece insanların istediklerini siyasal aktiviteler yoluyla elde etmeye çalışmalarını araştırmayı kapsamamalı, aynı zamanda "neden insanların ne istediklerini istemelerini" araştırmayı içerecek şekilde siyaset biliminin temel konularından biri olmalıydı.

Wildawsky’ye göre (1987:4), tercihler, sosyal etkileşim yoluyla açıklanabilen ilgilerden geliyorlardı ve eğer ilgiler sosyal ilişkilerin bir ürünüyse, tercihlerin kökleri de; "diğer insanlarla nasıl yaşamayı istiyoruz ve diğerlerinin bizimle nasıl yaşamasını istiyoruz" sorularının cevaplarında bulunabilirlerdi. ${ }^{10}$ Tercih oluşumu, öyleyse aynı anlamı paylaşan insanları bir araya getirecek bir sonuca sahipti. Wildavsky’ye göre (1987:4), eğer tercihler sosyal ilişkilerin organizasyonu yoluyla şekilleniyorlarsa, bu tercihler içerden gelmelilerdi, yani bizim "yaşam tarzlarımızdan” (ways of life). Bir başka deyişle, tercihler, "farklı yaşam tarzların savunma ya da muhalefet etmedeki sosyal etkileşimden” doğuyorlardı, çünkü Kültürel Teoriye göre bireysel kararlar ve seçimler, "paylaşılan değerler" ve sosyal ilişkiler ile beraber yürüdüğü için, aynı zamanda kültürlerin seçimiydiler (Wildavsky, 1987:5-6). Wildavsky (1989:1343), yaşam tarzlarını, insanların "ne için ve kime karşı sorumluyum?” sorularına cevap vermesine imkân veren normatif yapılar olarak tanımlamıştı.

Wildavsky’ye göre (1987:6), Kültürel Teorinin boyutları iki sorunun cevabına dayanıyordu: “Ben kimim?” ve “ne yapmalıyım?". İlk soru, grup bağlarının sıkı ya da zayıf olup olmaması gibi birey ile grup arasındaki ilişkinin niteliğini ölçmeye yönelikti (Wildawsky, 1987:6). İkinci soru ise, birey-grup ilişkisi dikkate alındığında, bireyin bağlı olduğu "kuralların" (prescriptions) niteliğini ölçmeye yönelikti (Wildavsky, 1987:6). Wildavsky’ye göre (1987:6), bu ikisinin kombinasyonu, sosyal ilişkilerin 4 kalıbını ortaya çıkarıyordu;

\section{Dört Kültür Modeli (Wildavsky, 1987:6)}

Kuralların Sayısı ve Çeşitliliği Grup Sınırlarının Kuvveti

\begin{tabular}{|c|c|c|}
\hline & Zayıf & Güçlü \\
\hline Sayıca Fazla ve Çeşitli & $\begin{array}{l}\text { Apati / Duyarsızlı } \\
\text { (Kadercilik) }\end{array}$ & Hiyerarşi (Kolektivizm) \\
\hline Sayıca Az ve Benzer & Rekabet (Bireycilik) & Eşitlik (Eşitlikçilik) \\
\hline
\end{tabular}

Benzer bir çalışma için ayrıca bkz. (Matjan, 1998).

10 Wildavsky’ye göre (1987: 5), Kültürel Teori, neyin, insanların çoğunun diğer insanlarla ilişkilerinde ve diğer insanların da onlarla ilişkilerinde önemli olduğu postulasına dayanıyordu. 
Sosyal ilişkilerin bu 4 kalıbı sadece toplumsal tercihleri değil, aynı zamanda siyasal ve ekonomik tercihleri de belirlemekteydi (Wildavsky, 1987:13). Diğer taraftan "sosyal yaşamın bu organizasyon modlarından" hiçbiri, kendi başına yaşayamayıp, bilakis bu kalıplar birbirleriyle etkileşim halindeydiler ve "kültürler arasindaki çatışma kültürel kimliğin bir önkoşulu" olarak ortaya çıkmaktaydı (Wildavsky, 1987:7; Wildavsky ve Dake, 1990:43-44).

Bu 4 kalıba göre, toplumsal tercihler şöyle açıklanmaktaydılar:"Bireyselci” kültürün sosyal ideali "rekabetçilik" ve "özdüzenlemeydi”, bu, bir taraftan otoriteye ihtiyacı en aza indirmeyi, diğer taraftan ise "sosyal farklilıkları azaltacak merkezi dağıtıcı bir otoriteyi" kapsıyordu (Wildavsky, 1987:611). Buna karşın, "Hiyerarşi", eşitsizliğe dayalı "kurumsallaşmış bir otoriteydi", uzmanlaşmayı ve işbölümünü, insanların beraber yaşamalarını daha iyi mümkün kılacakları gerekçesiyle meşrulaştırıyordu (Wildavsky, 1987:6-7). Wildavsky’ye göre (1987:6-7), hiyerarşiler, "parçaların bütün için kurban edilmesine" dayalı bir etik ile "rasyonelleştirilmekteydiler". "Eşitlikçi” kültür, otoriteyi reddederken, bir grubun parçası olması gereği, grup kararlarına uymak durumundaydı (Wildavsky, 1987:7-11). Ve son olarak "ne olacaksa, o olacak" şeklinde "kaderci" duygulara sahip olan "Duyarszz" kültür, "insanlarm kendilerine ne olduğunu kontrol edemedikleri" ve bu yüzden otorite ile ilgilenmedikleri kültürdü (Wildavsky, 1987:6-7).

Peki, eğer sosyal yaşam siyasal tercihlerin bir sebebiyse, tercihler nasıl oluşmaktaydılar? Wildavsky, bu soruya, toplumda paylaşılan anlamlar çerçevesinde cevap vermeye çalısmıştı. Wildavsky'ye göre (1987:8), "Kültürün kodları" çözülebilirdi, çünkü "anlamlar paylaşıldı̆̆ı" için "anahtarları sosyal" idi, temel tercihlerin bulunup çıkarılmasıyla, örneğin "onlar kim veya kim değil, hangi gruplara ait veya ait değiller" soruları yoluyla, gerisi bulunup çıarılabilirdi. Ancak burada tercih, sadece bir gruba bağlı oluşun getirdiği bireysel bir karardan ziyade, "öteki kültürlerin karşıtllğında" ortaya çıan, "belirli bir kültürün taraftarları arasindaki sosyal etkileşimin" bir sonucu olarak görülmeliydi (Wildavsky, 1987:9).

Wildavsky (1987:9-11), ayrıca, siyasal ve kamusal tercihleri açıklamanın temelinin, siyasal kültürler tarafından kategorize edildiği gibi sosyal ilişkilerde yattığını savunmaktaydı ve siyasal kültürlerin tanımlanmasında kullanılan sağ-sol ayrımı gibi dikotomilerin siyasal analiz için açıklık yerine belirsizlik yarattığını ifade etmişti. Diğer taraftan Wildavsky (1987:12), bir siyasal analiz için iki şart belirtmişti; "tarihsel bağlamlar" ve "paylaşılan anlamlarm ortaya çıkardığ iç tartı̧̧malar". Wildawsky (1987:12), bu ikisinin özüne vakıf olmadan, neden bir kültürün "belirli bir zamanda" belirli bir "kurumsal düzen ve politikalar" tercih ettiği ve neden diğer bir kültürün de diğer bir "kurumsal düzen ve politikalar" istediğini, açıklamanın mümkün olmayacağını belirtmişti. ${ }^{11}$ Wildavsky (1987:17), siyasal kültürü, "gücü yerleştirmenin bir yolu" olarak tanımlamıştı. Wildavsky ve Dake (1990:43-44) ise, "toplumsal olarak uygulanabilen kültürel önyargı ve toplumsal ilişki bileşimlerini, yaşam biçimleri veya siyasal kültür" olarak tanımlamışlardı.

11 Wildavsky ve Dake (1990:43), tehlike algısının siyasal kültürün bir işlevi olduğunu öne sürerek, siyasal analiz için diğer bir yöntem olarak risk analizini önermişlerdi, çünkü "bireylerin neden ve ne kadar korktuklarl, seçtikleri kendi yaşam tarzlarıyla (way of life) uyumlu” idi. Wildavsky (1987:14), riskin, bireyselci ve hiyerarşik kültürlerde kabül gördüğünü, eşitlikçi kültürde ise riske karşı bir isteksizlik olduğunu savunmaktaydı. 
Wildavsky’nin tezleri böyle özetlenirken, bu tezlere getirilen eleştirilerden ilki metoda yönelikti, çünkü Brendon Swedlow’a göre (2002:279), Kültürel Teori’nin kültürü anketler yoluyla ölçmesi, siyasal bilgilenmenin daha çok partiküler yapılar ve ihtisaslaşma yoluyla oluşmasından dolayı, gözden geçirilmeliydi. David D. Laitin (Laitin ve Wildavsky, 1988:589-593) ise, konseptin kültüre ilişkin yaklaşımına şu eleştirileri getirmişti; "1) Kültür tutulacak değerleri getirmiyor, tartışılacak noktalar sağllyor, 2) Kültür iki başl (Janus-faced): insanlar hem kültürlerinin sembolleri tarafindan yönlendiriliyorlar, hem de insan, kültürü kullanarak güç ve servet kazanmayı istiyor, 3) Kültür sembollerde işliyor ve semboller etnoğrafik bağlamda yorumlanmali". Yine Laitin’e göre (Laitin ve Wildavsky, 1988:590), Wildavsky sadece paylaşılan değerlere odaklanarak, muhalif görüşlere sahip olan kişilerin aynı kültürü paylaşabileceği ihtimalini gözden kaçırmıştı.

Buna karşın Wildavsky ise (Laitin ve Wildavsky, 1988:593-595), Laitin’i, Kültürel Teorìyi anlamamakla ve nominalizme geri dönmekle suçlamıştı. Wildavsky (Laitin ve Wildavsky, 1988:593), Laitin'in önerisinin, bir ülkede bir grupla özdeşleşen bir kültür yerine, muhalif kültürlere yönelik ise kabul edilebilir olduğunu belirtiyordu. Wildavsky’ye göre (Laitin ve Wildavsky, 1988:593), bir kültüre bağllık iki boyutun ölçülmesiyle belirlenmekteydi; "grup sınırının kuvveti" ve "kuralların derecesi ve çeşitliliği". Bu manada Wildavsky (Laitin ve Wildavsky, 1988:593), tercihlerin, kültürel tanımlamanın bir sebebi olmaktan ziyade, bir sonucu olduğunu belirtmekteydi. İkinci eleştiriye yönelik olarak ise Wildavsky (Laitin ve Wildavsky, 1988:594), Laitin’in siyaseti, sosyal yaşam ve ilişkilerden ayrı ve onların üzerinde düşündüğünü söylemişti. Son eleştiriye yönelik olarak ise Wildavsky (Laitin ve Wildavsky, 1988:595-596), "grid" ve "group" boyutlarının, kültürel kategorileri oluşturduğunu ve yaşam tarzlarına olan yakınlığın göreceli derecesinin ölçülebileceğini belirtmişti.

Richard W. Wilson (2000:265) ise, siyasal kültürü tanımlamada temel problem olan mikro-makro problemine dikkat çekmişti. Wilson’a göre (2000:265), siyasal kültür bireylerin tercihleri olarak ele alındığında mikro düzeyde ele alınmış oluyord. Wilson buradan yapılacak bir makro siyasal açıklamanın yetersiz olacağını öne sürüyordu. Wilson (2000:266), ayrıca makro siyasal kültür için genel bir tipoloji denemesi yapılmadığı gibi makro düzeyde gerçekleşen siyasal eylemlerin, bireylerin seçimini nasıl etkilediğine dair bir açıklamanın da yer almadığını belirtmişti. Wilson (2000:266), bireylerin herhangi bir toplumsal ambargoya maruz kalmamak için belirli tercihlerini açıklamaktan sakınmış olma ihtimallerinin açıklanmadığını da eleştiriyordu. Wilson (2000:268), son olarak, siyasal kültür ile tercihler arasındaki dinamik ilişkiyi ortaya çıkaracak bir kuramın genel olarak başarılamamış olduğunu, çünkü siyasal kültürün sadece tercihlerin bir ürünü olmadığı gibi tercihlerin de sadece siyasal kültürün bir yansıması olmadığının hesaba katılmadığını öne sürmüştü.

Öte yandan bu eleştiriler, Kültürel Teori’yi temel alan başka yaklaşımların ortaya çıkmasına vesile oldular. Bu yaklaşımlardan biri Virginie D. Mamadouha ait. Mamadouh (1999b), siyasal kültürü, Kültürel Teori ile Daniel J. Elazar ${ }^{12}$ tarafından Amerikadaki alt kültürlerin ele alındığ 1

12 Elazar’ın çalışmasının bir değerlendirmesi için ayrıca bkz. (Morgan ve Watson, 1991; Sharkansky, 1969). 
çalışmada ortaya atılan siyasal kültür tipolojisini kombine ederek tanımlamayı hedeflemekteydi. Bunun sebebi siyasal kültür kavramının içerdiği problemlerdi. Mamadouh (1997:18), bireysel tutum ve değerler ile kolektif tutum ve değerler arasında bağ kurmanın zor olduğunu, çünkü bireylerin oryantasyonların toplamının kolektif kültürü vermeyeceğini iddia etmişti. Mamadouh (1997:18-19), değerlerin hem bireylerin hem de kolektifliğin bir sıfatı olduğunu, ancak kültürün bir topluluğa dayandığını ve bu yüzden yapılacak bir siyasal kültür tanımının da "bireysel özel çıkarlar” ile "kamu yararı" arasındaki etkileşimi dikkate alması gerektiğini belirtmekteydi.

Mamadouh'un yaklaşımının Kültürel Teori yanında diğer dayanağı olan Elazar (1994:9), Amerikan siyasetindeki iki temel görüş olan, özgürlügün merkezi öneme sahip olduğu "Piyasa" ile eşitliğin merkezi öneme sahip olduğu "Ulus” karşıtlığından yola çıkarak Amerika’da şu 3 kültürün var olduğunu söylüyordu: 1) "Demokrasi” eşittir "Piyasa” düşüncesine dayalı "bireyselci siyasal kültür", 2) Demokrasi eşittir "Ulus" düşüncesine dayalı "morale dayalı siyasal kültür", ve 3) "Piyasa" karşısında bir "ikircikli tutuma" sahip ve "ulusun, paternalist konseptinde" yatan "geleneksel siyasal kültür".

Mamadouh’a göre (1997:19), Kültürel Teori, kültürel "bias”, yani ortak "değer ve inanışlar", ile "sosyal ilişkiler" (insanlar arası ilişkilerin kalıpları) arasındaki ilişki temeline dayanıyordu. Buna göre, bir "yaşam tarzı", "sosyal ilişkiler” ile kültürel "bias” olgusunun uyumlu bir kombinasyonunu oluşturuyordu (Mamadouh, 1997:19). Bu teori Mamadouh’a göre (1997:19; 1999a), Douglas tarafından "sosyabilitenin" iki boyutu olan "Group” ve "Grid” tezinden hareketle, bireylerin sosyal yaşama katılımlarının çeşitliliğini ölçmek için geliştirilmişti. Bu iki boyut, insan yaşamının şu iki sorusuna dayanıyordu: “Ben kimim?” ve “Nasıl davranmalıyı?” (Mamadouh, 1997:19). Mamadouh'a göre (1997:19), bu, hem sosyal bağlamlar ile bireysel eylemleri, hem de sosyal ilişkiler ile onların meşrulaştırılmalarını (justifications) karakterize etmeye yönelik bir araçtı ve siyasal kültüre de uygulanabilirdi. Mamadouh'a göre (1997:19-20), "sosyabilitenin" bu iki boyutu, "sosyal ilişkilerin" ve bunlarla bağlantılı "rasyonelliklerin" 4 temel formunu üretiyordu;

1) "Bireyci yaşam tarzı, zayıf grup ve az sayıda kural ile nitelendirilir.

2) Hiyerarşik yaşam tarzı, toplumsal roller göre değişen kuvvetli grup ve çok sayıda kural ile nitelenir.

3) Eşitlikçi yaşam tarzı, güçlü entegrasyon ve zayıf kural ile nitelendirilir.

4) Kaderci yaşam tarzı, insanları, başlarına gelecekleri kontrol edemeyen kişiler olarak niteler: entegrasyon düşük ama kurallar çok sayıdadır.” 


\section{Grup ve Grid Boyutlarıyla Dört Yaşam Tarzı (Mamadouh, 1997:20)}

\begin{tabular}{lll} 
Yüksek Grid $\uparrow$ Fatalizm & Hiyerarşi \\
\cline { 2 - 3 } & Düşük Grup & Eşitlikçilik \\
\cline { 2 - 3 }
\end{tabular}

Mamadouh bu noktadan itibaren Kültürel Teori'den ayrılmaktaydı, çünkü Mamadouh'a göre (1997:21-22) Kültürel Teori, “yaşam tarzlari” ile siyasal kültürü eşdeğer olarak görüyordu. Buna karşın, Mamadouh (1997:21-22), siyasal kültürün bireylerden ziyade bir siyasal topluluğun özelliği olduğunu ve bu yüzden de "yaşam tarzları" ile bir tutulamayacağını iddia etmişti. Mamadouh'a göre (1997:23-24), siyasal kültür, “yaşam tarzlarını”” kendisinden ziyade, onlar arasinda kurulan stabil “ittifaklar” olarak görülmeliydi. Mamadouh (1997:23-24), bu ittifaklar ile Elazar’’n tipolojisini harmanlayarak 3 ayrı siyasal kültür tipi önermişti;

1) "girişimci"; Bu siyasal kültür tipini belirgin yapan, "bireyci” ve "hiyerarşik yaşam tarzı" arasında kurulan ittifaktı.

2) "ahlakçı"; Bu siyasal kültür tipini belirgin yapan, "hiyerarşik" ve "eşitlikçi yaşam tarzı" arasındaki ittifaktı.

3) "geleneksel”; Bu siyasal kültür tipini belirgin yapan ise; "büyük çoğunluğu kadercilerden oluşan bir rejimde hiyerarşik yaşam tarzının istikrarlı hegemonyasıydı". ${ }^{13}$

\section{Sembol Odaklı Yaklaşımlar}

Antropoloji içerisinde kültürü tanımlama bakımından semboller önemli ilgi kaynaklarından birini oluşturmaktaydılar (White, 1940; 1947; Kroeber ve Kluckhohn, 1952; Jaeger ve Selznick, 1964). Bu ilgi, 1960’lı yıllardan itibaren önemli bir ilerleme kaydetmeye başladı. Bunda en büyük pay hiç şüphesiz Clifford Geertz'e aitti. ${ }^{14}$ Geertz, Parsons'in desteğiyle gittiği Bali’de “horoz dövüşleri” üzerine yaptığı bir çalışmada, bu dövüşlerin kendisi dışında birçok şeyi sembolize ettiğini belirtmekteydi;

"Her şeyin ötesinde Balinese halkı horoz dövüşlerinde kendilerini, toplumsal düzenlerini, soyutlaşan nefretlerini, erkekliklerini, şeytani güçlerini görüyorlar; tüm bunların yanında kibirli, yiğit, onur düşkünü ateșli oyuncular, ksatria prensi ile birlikte statü değerinin ilk

13 Mamadouh (1999b: 479), daha sonra bu tipolojiye, 2 siyasal kültür tipi daha eklemiști; "clientelistic" ve "obstructive”. 
örneklerini görüyorlar. (...) Bir imaj, hayal ürünü, bir model, bir metafor olarak horoz dövüşü kendini ifade etmenin bir aracıdır; onun amacı ne toplumsal hırsları yatıștırmak ne de artırmaktır (yine de, ateșle oynar gibi bu ikisini de yerine getirir), ama, tüyler, kan, izleyiciler ve para arasinda bunlar da sergilenir. (...) Gerginlik kendini "bir yolunu bulup" şu özelliğiyle gösterir: anlık dramatik şekli; metaforik içeriği; ve toplumsal bağlamı.” (Geertz, 1972:23-24)

Geertz’ in bu tezi, karşılığını ilk olarak Antropoloji içerisinde yeni kültür tanımlamalarında buldu ve kültür; "semboller, hikâyeler, ritüeller ve dünya görüşlerinden" oluşan bir "tool kit" (Swidler, 1986:273) olarak görülmeye başland. Geertz’in kültürü, “tutumların bir setinden” çok, bir "semboller seti ve bu sembollere yerleşmiş ritüeller" (Laitin, 1995:169) olarak görmesi, kültür ile siyasal kurumlar arasındaki ilişkiyi ele almak isteyenlere de önemli bir esin kaynağı oldu (Welch, 1993:99-108; Pye, 1991a:503). Bu sürece etki eden ikinci bir gelişme ise, sembollere karşı siyaset bilimi içerisinde önemli bir ilginin oluşmasıydı (Edelman, 1960; Cobb, 1973; Walzer, 1967). ${ }^{15}$ Sonuçta, teori ve metot bakımından farklı temellere sahip olmakla beraber, bu gelişmelerden etkilenen, siyasal kültürü tanımlamaya yönelik yeni yaklaşımlar ortaya çıktılar (Schwelling, 2001:609-611). Bu yaklaşımlar arasında özellikle iki isim göze çarpmaktaydı; Lowell Dittmer ve Karl Rohe.

\section{Lowell Dittmer}

Siyasal kültürü tanımlamaya yönelik sembol odaklı yaklaşımlar içerisinde önemli bir yer edinen ilk isim Lowell Dittmer (1977; 1980) idi. Dittmer'a göre (1977:555), The Civic Culture, siyasal kültürü, bireylerin siyasete ilişkin tutumlarının toplamı olarak tanımlayarak bir "psikolojik indirgemecilik" temeli üzerine inşa etmişti. Bu temel, siyasal kültürün bir yandan siyasal psikoloji ve diğer yandan ise siyasal yapı tarafından sinırlandırılmasından kaynaklanıyordu ve ayrıca siyasal kültürün kendisi ile siyasal yapı arasındaki ilişkiyi açıklamada yetersiz kalmasına sebep olmuştu (Dittmer, 1977:555-556). Son olarak, kuramın siyasal sistemin stabil kalmasını açıklamaya odaklanması, onun başarısını kısıtlayan bir diğer temeliydi, Dittmer’n (1977:556) ironik bir şekilde sorduğu gibi; "değişimin olmaması bir açıklama gerektiriyormuş gibi”. Peki, o zaman, siyasal kültürü, onu sınırlandıran bağlardan kurtaracak şekilde tanımlamanın yolu neydi? Dittmer’ın (1977:555-567) bu soruya verdiği cevap, siyasal kültürün siyasal değer ve inanış sistemlerinin toplamını aşacak şekilde, siyasal semboller üzerinden tanımlanması ve analizi yönündeydi.

Neden semboller? Dittmer (1977:557-563), bu soruya şöyle cevap vermişti; a) semboller insanlardan bağımsız olarak varlar, b) bu yüzden anlamlarını, zaman ve mekândaki büyük uzaklıklara rağmen kişiden kişiye aktarabilirler, c) semboller ampirik bir değişken olarak hem siyasal psikolojiye hem de siyasal yapıya çok yakın, ama her ikisinden bir dereceye kadar bağımsızlar, d) içyapılarının analize açık olması sebebiyle, siyasal kültürü, statükoyu koruma ve sistemler arası çatışmaları minimize etme işlevi görür yönündeki hâkim kabulden kurtarabilecek

15 Bu ilginin nedeni, Walzer’n (1967: 194) şu cümlesinden anlaşlabilir; "Devlet görünmezdir; görünebilmesi için ete kemiğe bürünmesi, sevilmesi için sembolize edilmesi, tasarlanmast için hayal edilmesi gereklidir”. 
durumdalar. Fakat semboller de bazı handikaplara sahiptiler, örneğin a) o kadar değişik perspektiften ele alınmış durumdalardı ki en azından siyasal kültür kadar belirsiz oldukları söylenebilirdi. Bunun yanında, ayrıca, b) semboller ile dil ve siyasal yapı arasındaki ayrımın başarısız olması, c) sembollerin çok çeşitli tiplere sahip olmaları, d) siyaset bilimi içerisinde sembolik süreçlerin analizine yönelik bir kuramın yokluğu gibi faktörler de sembolleri belirsiz bir hale getirmekteydiler (Dittmer, 1977:557-563).

Dittmer (1977:563-566), bu problemleri çözmek ve siyasal kültürü tanımlamada bir temel olarak kullanabilmek için, siyasal sembolizmin - "dilbilimsel" veya "linguistik" ve "iletişimsel" boyutlarını da içerecek șekilde- "iletişim" ve "bilgi" teorileri ile bir sentezini oluşturmaya çalışmıștı. Dittmer (1977:566), bu noktada siyasal kültürü bir "semiyolojik sistem" olarak tanımlamıştı. ${ }^{16}$ Dittmer’a göre (1977:566), bu semiyolojik yaklaşım sembollere odaklanmaktaydı, çünkü siyasal kültür, siyasal sembollerin bir sistemiydi ve bu sistem siyasal komünikasyon olarak adlandırılan daha kapsamlı bir sistemin içine yuvalanmış durumdaydı.

Dittmera göre (1977:566), siyasal komünikasyon sistemi bir taraftan kodlar, gönderici, kanallar gibi komünikasyon teorisinin bileşenlerini, diğer taraftan ise "göstergeler", "göndergeler" ve "anlamlar" gibi belirli dilbilimsel kategorileri içeriyordu. Siyasal semboller ile siyasal dil arasındaki ayrımı, Dittmer (1977:567), siyasal sembollerin siyasal dilden daha fazla içerdiğini iddia ederek çözmeye çalışmıştı. Semboller amblemleri, ikonları (bayrakları, totemleri, sikkeleri), grafiksel artifaktları (heykelleri, resimleri) ya da somut varlıkları (Kudüs, Kremlin) içerebilirdi (Dittmer, 1977:567). Dittmer (1977:567), bununla beraber, sözlü sembollerin sözlü olmayan sembollerden daha kapsayıcı olduğunu kabul ediyordu. ${ }^{17}$ Ayrıca Dittmer’a göre (1977:567), siyasal sembolizm, kendini siyasal dilden ayıran iki özelliğe sahipti: "üstdilsel" (metalinguistic) özelliği ve "çağrışımsal" özelliği ${ }^{18}$ Sembollerin "üstdilsel" özelliği, onların görünürde "amaç" ya da "nesne dili" (object language) ve güncelde "metadil" (metalanguage) olarak işlev görmeleriydi, yani, özel bir ampirik olay gösterir gibi görünürken, gerçekte bir göstergeler dizisine referans göstermeleriydi (Dittmer, 1977:567). Dittmer’a göre (1977:568), bu “üstdilsel” özellik şöyle tasvir edilebilirdi;

\begin{tabular}{|c|c|c|c|}
\hline \multirow[b]{2}{*}{ METADİL } & \multicolumn{3}{|c|}{ Sembol } \\
\hline & \{ & & Çağrışım \\
\hline NESNE DİLİ & $\left\{\begin{array}{l}\text { İşaret eden } \\
\text { (Signifier) }\end{array}\right.$ & $\begin{array}{l}\text { İşaret edilen } \\
\text { (Signified) }\end{array}$ & \\
\hline
\end{tabular}

16 Dittmer (1977: 566), modelini bir dizi mantıkçının çalışmalarına, kültür antrapologların çalışmalarına ve Charles Morris'ten Roland Barthes’e kadar bir dizi yapısal dilbilimcilerin çalışmalarına dayandırıyor.

17 Benzer bir sonuç için ayrıca bkz. (White, 1940: 462 -463; 1947: 687).

18 "connotative" kelimesi Türkçeye ima eden, çağrışım yapan olarak tercüme edilebilir. Burada kelime Türkçeye çağrışımsal olarak tercüme edildi. 
Dittmer’a göre (1977:568), sembollerin “çağrışımsal” özelliği, onun duyguları temsil etme ve iletme kapasitesine gönderme yapıyordu ve bu yüzden de siyasal kültürü analiz etmek bakımında önemliydi. Çünkü Dittmer’a göre (1977:569-570), siyasal kültürün özünü insanların siyasete ilişkin hisleri oluşturuyordu ve bir sembol, geniş çaplı ilgi ve duyguların emanetçisi konumuna gelmedeki başarısının derecesine göre siyasal davranışı etkileyebilirdi. Diğer taraftan Dittmer (1977:570), siyasal kültür sistemi içindeki “ileteşenleri”, işlevlerine göre iki kategoriye ayırmıştı: sembolleri manipüle eden elitler ve elitlerin yeteneğine ve ilgilerin örtüşmesine bağlı olarak sembolleri yorumlayan ve buna uygun bir şekilde cevap veren kitle. Dittmer’a göre (1977:571), elitler ve kitle birbirleriyle semboller yoluyla ilişki kuruyorlardı;

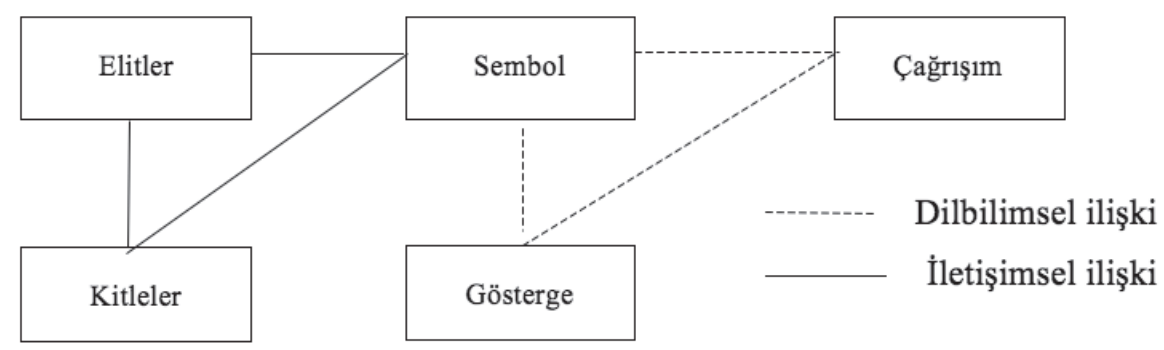

Dittmer’a göre (1977:571), siyasal kültürün bu sistemi, 3 semiyolojik ilişki temelinde analiz edilebilirdi: pragmatik, semantik ve sentaktik. Pragmatik konuşmacının ifade etme ya da birisine bir şeyi iletme amacına ve dinleyicinin reaksiyonuna odaklanarak kitle ve elitler arasındaki ilişkiye referans yapıyordu, semboller yoluyla aracılık edilmesi gibi (Dittmer, 1977:571-572). Burada kitlenin mümkün amacı muhalefet ya da destek, elitlerin amacı ise bu desteği ya da muhalefeti sembolik genişletmek olarak tanımlanabilirdi (Dittmer, 1977:572). Dittmer’a göre (1977:572), kitle ve elitler arasındaki ilişkiyi analiz edebilmek için, bu ikisi arasındaki temel çatışma noktasını belirlemek gerekmekteydi. Bu nokta, kitleler için "göreceli mahrumiyet" "göreli yoksunluk" (relative deprivation), ve elitler için ise "statü uyuşmazlı̆̆ı" (status incongruence) idi (Dittmer, 1977:572). Buna göre, kitleler arasındaki temel siyasal bölünme, mahrum olanlar ile memnun olanlar arasındayken, elitler arasındaki temel siyasal bölünme makam adayları ile makam sahipleri arasındaydı (Dittmer, 1977:572). Kitle ve elitler arasındaki bu ilişki şöyle kombine edilebilirdi (Dittmer, 1977:572);

\section{ELITTLERIN BEKLENTILERİ}

Muhalefeti Artırmak Desteği Artırmak

\section{KİTLE BEKLENTILERİ}

Muhalefet

\begin{tabular}{|c|c|}
\hline 1 & 2 \\
\hline 3 & 4 \\
\hline
\end{tabular}


Buradaki her bir ihtimal, kitle ve elitler arasındaki desteğin veya muhalefetin örtüşme derecesini gösteriyordu. Dittmer (1977:573), bir sonraki aşamada bu ihtimallerin olası sonuçlarını siyasal sistemin geleceği açısından semboller yoluyla analiz etmeye çalışmıştı.

Pragmatik bu şekilde özetlenirken, diğer bir nokta olan semantik, semboller ile sembollerin referans yaptığı siyasal gerçeklik arasındaki ilişkiyi karakterize ediyordu (Dittmer, 1977:571). Dittmer’a göre (1977:576), sembolün "üstdilsel” ya da "kavramsal" anlamının çekirdeğini oluşturma, orijinal göstergenin ampirik anlamıydı, ancak sembol bir şekilde çekirdek anlam ile bağlantı kurabildiği sürece öteki göstergelerin tanımlanmamış bir serisine kucak açabilirdi, güç ya da ebediliği sembolize etmek için gökyüzünün kullanılması gibi. Dittmer (1977:577), burada yapısal dilbilimcilere dayanarak sembollerin oluşumunda yalnızca iki temel prensip olabileceğini söylüyordu; "metonymie" ve "metafor". ${ }^{19}$

Sentaktik ise, göstergeler, konuşmacı, dinleyici ve gönderge arasındaki biçimsel ilişkiden ve bir sembol sistemindeki sembollerin iç organizasyonun şekilsel analizinden oluşmaktaydı (Dittmer, 1977:571-578). Dittmer’a göre (1977:578), yukarıda bahsedilen “çağrışımsal” içerik, sentaks tarafından nakledilme eğilimi gösteriyordu, ancak burada sentaktik düzenin 2 boyutu önemliydi; konuların "anlatı" tanzimi ve temalar arasındaki mantıksal ilişkiler. Dittmer (1977:579-581), sentaktik’e örnek olarak ise siyasal mitleri göstermişti.

Sonuç olarak, Dittmer’a göre (1977:581-582), siyasal kültürü tanımlamada yapılan bir hata, objektif bir siyasal gerçekliğin sübjektif bir algı yoluyla ölçülmesiydi ve bu herhangi bir ara değişkenin atlanmasına neden olmuştu. Dittmer (1977:582), eksik kalan bu ara değişkeni, siyasal sembolizm ile gidermeye çalıştığını belirtmişti. Dittmer’a göre (1977:582), amacın, siyasal sistemin altında yatan değer oryantasyonlarını ortaya çıkarmak olduğu sembollere dayalı böyle bir siyasal kültür analizi, anahtar semboller tespit edildikten sonra, bu semboller ile oluşan dilsel ve iletişimsel ilişkilerin semiyolojik bir çerçeveye yerleştirilmesiyle yapılabilirdi.

\section{Karl Rohe}

Sembol odakl yaklaşımlar içerisinde yer alan bir diğer yaklaşım Karl Rohe’ye (1987; 1990; 1994a; 1994b) ait. Rohe, tezlerinin büyük bir bölümünü, D. J. Elkins ve R. E. B. Simeon’’n düşüncelerine dayandırmıştı.

Elkins ve Simeon (1979:127), siyasal kültürü, siyasal fenomenlerin açılanmasında bir bileşen olarak görmekteydiler ve onu "siyasal dünya üzerine varsayımlar" olarak tanımlamışlardı. Bu şekliyle siyasal kültür, mantıksal mümkün alternatif davranışlar, problemler ve çözümlerin bir bütününü, onların sadece belirli olanlarıyla sınırlandırmaya yarayan bir "mind set" olarak

19 Dittmer’a göre (1977: 577), "Metonymie" bitişik elementlerin birbirinin yerine geçmesine dayalıydı ve "kapsamlayış" (synecdochy), ya da "pars pro toto" gibi bir şeyi ifade ediyordu, "Metafor" ise benzer elementlerin yer değiştirmesi anlamina geliyordu. 
görülmeliydi (Elkins ve Simeon, 1979:128). Elkins ve Simeon (1979:128-129), siyasal kültürün, "bir kolektifliğin özelliği” olduğunu, bireylerin değer, inanış ve tutumlara sahip olabileceklerini ancak kültüre sahip olamayacaklarını söylüyorlardı. Öyleyse siyasal kültür analizi, bireyler üzerinden değil, "elite political culture" gibi, ya da Almond ve Verbảnın yaptıkları gibi ulusal siyasal kültür araştırmaları üzerinden, çeşitli şekillerde tanımlanabilecek "kolektiflikler" üzerinden ve "kolektifliklerin" karşılaştırılması şeklinde yapılmalıydı (Elkins ve Simeon, 1979:139). Ayrıca, Elkins ve Simeon (1979:139-143), siyasal kültürün açıklayıcı güce, onun ancak kurumsal ve yapısal açıklamalarla beraber düşünüldüğü takdirde sahip olabileceğini iddia etmekteydiler.

$\mathrm{Bu}$ tezlerden oldukça etkilenen Rohe (1987:39), siyasal kültürü, siyasetin dünyasına özgün "tasavvurlar" ve bunlarla bağlantılı olan "operasyonel normlar bütünü" olarak tanımlamıștı. Rohe’ye göre (1987:39), bu normlar bir kolektifin siyasal yaşamla ilgili özel bir anlam ile yüklü düşünsel tasarımlarıydı. Rohe (1990:333), bu tanımı daha sonra Weber'in "siyasal dünya görüşü" ile birleştirerek, normal durumlarda "sosyal taşıyıcıların", bu siyasal dünya görüşündeki gerçeğe özgün tasavvurlar "doğal" ve "anlaşıllr" olarak hissedildikleri için, siyasal kültürün farkında olmadıklarını belirtmekteydi. Böylece siyasal kültür, özel bir anlam öbeği ile yüklü "çerçeve", ya da Elkins ve Simeon’a dayanarak, siyasal aktörlerin düşüncelerini, davranışlarını ve hissiyatlarını belirlemekten ziyade "yönlendiren" ve onlara koşullar koşan, siyasal bir "kod" haline dönüşmekteydi (Rohe, 1990:333; 1994a:1). Bu tanım, kültürü bir “mental map” olarak gören Pye (1997:245) tarafından savunulan düşüncelerle de örtüşüyordu. Daha sonra Rohe (1994b:163165), Karl Mannheim’a dayanarak siyasal kültürü; bir toplulukta herhangi bir toplumsal baskıya maruz kalmadan "ne ve nasıl, siyasal davranllir, siyasal konuşulur ve siyasal düşünülürü" belirleyen bir kurallar sistemi olarak tanımlamıştı.

Rohe’nin siyasal kültüre ilişkin görüşleri şu noktalarda Almond ve Verbảnın tezlerinden ayrılmaktaydı. Bir defa Rohe’ye göre (1987:39-41), siyasal kültür, Almond ve Verba’nın iddia ettiğinin aksine bireyler üstü bir karaktere sahipti. Rohe (1987:39-41), bireyleri, siyasal kültürün olmazsa olmazı olarak görmekteydi, ancak ona göre kültürün taşıyıcıları bireyler değil de, daha çok toplumsal kolektiflerdi. Diğer taraftan Rohe’ye göre (1994a:1), siyasal kültür, tutumlardan ziyade, "tasavvur kalpplarından" oluşmaktaydı, çünkü siyasal kültür, kanılara temel olan "algılama kalplarını" ve "değerlendirme kriterlerini" sorgulamalıyd1.. ${ }^{20}$ Buna göre, siyasal kültür politikanın algılandığı, yorumlandığı ve değerlendirildiği bir kriterdi (Rohe, 1994a:1; 1990:334; 1987:40). Rohe’ye göre (1987:40), önemli olan bir rejimin ne kadar kabul gördüğü ya da reddedildiği değildi, bu kabul ya da ret etmeye temel olan prensiplerdi. Çünkü Rohe’ye göre (1987:40), bir rejim üstüne olan kanılar çeşitli sebeplerden dolayı çabucak değişebilirken, bu durum, tasavvurların da değişeceği anlamına gelmiyordu. Bilakis, siyasal kültürün değişmesi ancak bir toplumun hafızasında kaydedilmiş “anlam birlikteliklerinin” değişmesi ile gerçekleşebilirdi (Rohe, 1987:41; 1990:334; 1994a:2; 1994b:165).

20 "Muster" kelimesi, "motif” anlamına da gelmekle beraber, burada İngilizce "patterns" kelimesine karşıllk gelecek şekilde kullanılmış. Bu yüzden Türkçeye "kahlp” olarak tercüme edildi. 
Öte yandan, Rohe (1994b:168), siyasal kültürün iki katmandan oluştuğunu iddia etmekteydi. ${ }^{21}$ "Yorumlama kültürü̈" (Deutungskultur), siyasal düşünceleri ve işaretleri kendi siyasal kültür ve grup çerçevesinde görmek manasına geliyordu ve siyasal dünyanın kim tarafından ve kimin için yorumlanacağı sorusuna dayanıyordu (Rohe, 1994b:168). "Yorumlama kültürü” böylece siyasal kültür içinde "Üstyapıyı" oluşturuyordu. Rohe'ye göre (1987:44), diğer katman olan "Sosyal kültür" (Soziokultur) ise "alt yapı" idi; "Sosyal kültür" içinde "siyasal tasarım, mantalitelere, alışkanlıklara ve yaşam şekillerine toplumsal olarak kristalize” olurdu. Rohe’ye göre (1987:42), siyasal kültürün bu iki katmanı arasında tartışılmaz “apaçıklıkların” kültürel tartışmalarla sorgulandığı, yeni siyasal "apaçıklıkların” oluşmasına yol açan bir değişim ilişkisi yaşanıyordu.

Peki, tutumlar yerine tasavvurları temel alan bir siyasal kültürün analizi nasıl yapılmalıydı? Rohe'ye göre (1994a:5; 1994b:163), kültürel değerlerin ve algı kalıplarının daha iyi anketler yoluyla mı yoksa davranışların gözlem ve analizi yoluyla mı ölçülebileceği açık bir soru olmakla beraber, siyasal kültürü ölçmek için siyasal dil ve sembollerin analizi, parti sistemleri analizi, siyasal davranışların gözlemi gibi değişik metotlar kullanılmalıydı. Siyasal kültürün kendisine ilişkin ise Rohe, çeşitli siyasal kültür tipolojileri sunmuş olmasına rağmen, bunlardan hangisinin temel alınması gerektiği konusunu açık bırakmıştı. ${ }^{22}$

\section{Bilgi Odaklı Yaklașımlar}

Edmund Husserl, Alfred Schütz, Peter L. Berger ve Thomas Luckmann'in fenomenoloji ve bilgi sosyolojisi, siyasal kültür araştırmaları içerisinde bir ilgi uyandırmış olmalarına rağmen, 2000'li yıllara kadar bu temelde sistematik bir siyasal kültür tanımı ortaya konulamamıştı. ${ }^{23} \mathrm{Bu}$ ilginin bir siyasal kültür tanımında somutlaşması ancak Birgit Schwelling (2001) ile mümkün oldu.

\section{Birgit Schwelling}

Schwelling, yaklaşımını, iki kültür tanımından yola çıkarak oluşturmaya çalışmıştı. Bunlardan ilki Almond ve Verba’nın da yararlandıkları Ruth Benedict'in (1960) kültür tanımıydı. Schwelling’e göre (2001:615), Benedict, kültürü, anlamlı ayrılmış, seçime göre sonsuz çok ve potansiyel nazır bulunan kültür elementlerinden oluşan bir "bütün” olarak tanımlamıştı. Bu tanım, Almond ve Verba’nın kültür tanımından hem oldukça uzak bir tanımdı, hem de değerler, semboller, davranışlar, kurumlar gibi kültürün diğer düzeylerini kapsıyordu.

21 Rohe değinmemekle beraber, benzer bir ayrım, oldukça uzun bir zaman önce F. Stuart Chapin (1934: 61-62) tarafından yapılmıştı.

22 Rohe (1987: 44-46) öncelikle siyasal kültür tiplerinin içeriğe göre değil de, siyasal yaşam için sahip oldukları işleve göre tanımlanması gereği üzerinde durmuş ve iki siyasal kültür tipi öngörmüștü; "siyasal yaşam tarzı olarak siyasal kültür" ve "siyasal dünya görüşü olarak siyasal kültür". Ancak Rohe, diğer makalelerinde bu ayrıma sadık kalmayarak farklı tipler öne sürmüştür (Rohe, 1994b: 171-175; 1994a:11-14).

23 Siyasal kültür ile fenomenoloji ve bilgi sosyolojisi ilişkisine değinen diğer çalışmalardan bazıları için ayrıca bkz. (Opielka, 2006; Lehman, 1972; Welch, 1993). 
İkinci olarak, Almond ve Verba, Benedict'in bu kültür tanımından hareketle siyasal kültürün elementlerinden yola çıkarak kendisine ulaşmayı hedeflemişlerdi. Oysa Benedict'e göre (1960:53), bu bütün ayrılmış elementlerin toplamı olarak görülemez ya da parçalarını birleştirerek bütün’e ulaşılamazdı. Çünkü Benedicte göre (1960:53), bu bütün, ayrılmış elementlerin özel bir şekilde bir araya gelmesiyle ve karşllıklı etkileşimiyle oluşmuştu. Schwelling (2001:615), bu kültür tanımından iki sonuç çıkarmışt1; 1) kültürel fenomenler, kültürel bir kesit ve bu kesiti oluşturan elementler arasındaki ilişkilerle ilgili, bu bağlamda kültür analizi yapmak, bu ilişkileri analiz etmek anlamına geliyor, 2) bu ilişkiler kültürel analiz düzeyini sınırlandırmıyorlar. O zaman, Benedict tarafından ortaya atılan bu kültür tanımı, Schwelling’e göre (2001:616), ne mikro düzeye yoğunlaşan Tutumlar odakl yaklaşımlarla ne de meso ve makro düzeye yoğunlaşan Sembol odaklı yaklaşımlarla bağdaşıyordu. Bu yüzden, temel alınacak kültür tanımı, hem bu açık noktaları kapatmalı, hem de "siyasal önemli fenomenlerin kültürel temellerini" (Schwelling, 2001:617618) analiz etmeyi mümkün kılmalıydı. Schwelling’e göre (2001:618), bu kültür tanımını bilgi sosyolojisi sunmaktaydi.

Schwelling (2001:618), yaklaşımını, bilgi sosyolojisinin iki temel kavramı üzerine kurmuştu: "bilgi" ve "yaşam dünyasi" (Lebenswelt). Schwelling'e göre (2001:618), Alfred Schütz "yaşam dünyasını", "normal ve sağlkkl düşünebilen bir yetişkinin basitçe bulduğu her gerçeklik alanı" olarak tanımlamıştı. Buradaki "basitçe" ile sormadan şüphesizce yaşanılan her şey ve başka bir noktaya kadar problemsiz gözüken her durum kastediliyordu (Schwelling, 2001:618). Schwelling’e göre (2001:618), bu tanım, fenomenolojinin iki kabulüne dayanıyordu. Bunlardan ilki, eylemde bulunanın, "yaşam dünyasının" irdelenmeden bulunacağına, yani yaşamın bugün nasıl ise yarın da öyle olacağına, dair kabulüydü (Schwelling, 2001:618). Schwelling’e göre (2001:618), Schütz ve Luckmann bunu Husserl'den aldıkları iki kavramla açıklamışlardı; "ve böyle devam" ("und so weiter") ve "ben her zaman yapabilirim" ("ich kann immer wieder"). ${ }^{24}$ İlk kavram, dünyanın şimdiye kadar tanıdık şekliyle, yine öyle kalacak olmasını ve bunun sonucunda da, insanın kendi tecrübelerinden oluşturduğu ve kullandığı "bilgi stokunun"25 ("Wissensvorrat") temel geçerliliğini korumaya devam edecek olmasını belirtiyordu (Schwelling, 2001:618). Bu gerçeklik beraberinde diğer bir temel kabulü getiriyordu; eğer, dünya, şimdiye kadar bilindik şekliyle değişmeden kalacaksa, insan daha önce yapmış olduğu "başarılı davranışlarını tekrar edebilirdi” (Schwelling, 2001:618).

Yaşam dünyasının bir başka özelliği, onun bireylerarası (intersubjektivität) olmasıydı. Bu, yaşam dünyasındaki gerçekliğin temel yapısının tüm katılımcılar için ortak olduğu anlamına geliyordu, yani bireyin "bir ölçüye kadar" yaşamdaşlarının davranışlarının amacından haberdar iken, aynı şekilde başkalarının da onun davranışlarının amacından haberdar olduklarını kabul etmesi anlamına geliyordu (Schwelling, 2001:619). Yaşam dünyasının bu iki temel özelliği, "kültürel bir birliğin mensupları tarafindan paylaşılan ve yaşam dünyasında oryantasyon için ihtiyaç duydukları",

24 Schwelling burada şu esere atıf yapıyor: Schütz, Alfred/ Luckmann, Thomas (1975); Strukturen der Lebenswelt, Neuwied: Luchterhand, (Soziologische Texte; Bd. 82), 1975.

25 "Wissensvorrat" Türkçe’ye bilgi haznesi, bilgi stoğu ya da bilgi birikimi olarak çevirilebilir. Burada bilgi stoğu olarak tercüme edilmiştir. 
"bilgi stoklarma" dayanıordu (Schwelling, 2001:619). ${ }^{26}$ Öyleyse birey, bu "bilgi stoklarına" sahip olmadan, "durumu", "anlamlandırma" ve "yorumlama" imkânına sahip olamazdı (Schwelling, 2001:619).

Schwelling’e göre (2001:619), Schütz ve Luckmann burada "toplumsal" ve "sübjektif bilgi stoklart" diye ikili bir ayrıma gitmişlerdi. ${ }^{27}$ Schwelling (2001:620), özellikle "toplumsal bilgi stoklarmın" Benedict tarafından savunulan kültür konseptiyle uyum sağladığını ve bu yüzden siyasal kültür tanımı için kullanılabileceğini belirtmekteydi. Buradan hareketle Schwelling (2001:619-620), kültürü, "kendi tipolojik yapısinda bir kalı olarak bütün yaşam belirtilerine temel olan bilgi stoklarından bir tanesi" olarak tanımlamıştı. Schwelling (2001:619-622) burada 3 temel amaca sahipti; 1) siyasal kültürü mikro düzeyden kurtararak, onu mikro, meso ve makro düzeyleri de içine alacak şekilde tanımlamak, 2) böyle bir kültür tanımı yardımıyla sosyal yapı ve tarihsel bağlamlara bağlantı kurmak, 3) kültürel temellendirilmiş güç dağılımı mekanizmalarını göstermek.

“Toplumsal bilgi stoklari”, Schwelling’e göre (2001:620), bu amaçları gerçekleştirmek için gerekli temeli oluşturmaya uygundular. Bir defa "Toplumsal bilgi stoklari" daha önceki mikro odaklı kültür tanımlarında olağan görüldüğü gibi "sübjektif bilgi stoklarının" bir toplamı değillerdi, bilakis onun ile etkileşim halindeydiler (Schwelling, 2001:620-622). Ayrıca bireylerarası, objektifleştirilmiş, kurumsallaştırılmış ve sosyal yapılara ve tarihsel bağlamlara bağlı olmaları sebebiyle de bir analiz düzeyi olarak görülebilirlerdi (Schwelling, 2001:622). Schwelling’e göre (2001:622), böylelikle, diğer yaklaşımlar tarafından dışlanan tüm analiz düzeyleri irdelenebilirdi.

\section{Sonuç}

$\mathrm{Bu}$ makalenin amacı, siyasal kültür araştırmaları’nın günümüzde geldiği düzeye ilişkin bir değerlendirme yapmaktı. Bu kapsamda, her ne kadar sayıca tüm yaklaşımlar içerisinde ancak çok küçük bir porsiyonu temsil ediyorlar olsalar da, "Tutumlar odakl", "Sembol odaklı" ve "Bilgi odaklı yaklaşımlar" içerisinde yer alan çalışmalardan belli başlı olanlar ele alındılar.

Burada ele alınan yaklaşımlar, her şeyden önce, siyasal kültür araştırmaları'nın dinamik bir yapıya sahip olduklarını gösteriyorlar. Öyle ki, siyasal kültür, ilk ortaya çıktığı anlamın dışında, çok farklı yönlerden ele alınmış ve tanımlanmış durumda. Ancak bu dinamik yapı, ilk bakışta olumlu görünmekle beraber, aslında siyasal kültürün bir teori olarak yerleşmesini olumsuz yönde etkileyen nedenlerin başında geliyor. Çünkü bu dinamik yapı, birçok yeni siyasal kültür tanımının ortaya çımasına vesile olmasına rağmen, arkasında, üzerinde belirli bir konsensüsün

26 Schütz (Schütz ve Parsons, 1977: 112-113), bu nokta da Parsons’un düşüncesinden ayrllyyor. Aslında kültürel sistemleri, Parsons gibi Schütz’de "eylem süreçlerinin" (Handlungsprozesse) "ürünleri" olarak görmesine rağmen, onu "eylem kategorilerinden" (Handlungskategorien) çıkararak objektif bir düzeye getiriyor. Parsons ise (Schütz ve Parsons, 1977: 121), Schütz’ün böyle bir yorumla "Eylem Teorisinin” (Handlungstheorie) düzeyini göz ardı ettiğini düşünüyor.

Benzer çalışmalar için ayrıca bkz. (Berger ve Luckmann, 1990; Berger ve Kellner, 1965). 
oluştuğu ne bir tanım, ne de bir metot bıraktı. Bugün siyasal kültür analizi yapmak isteyen birisinin cevaplaması gereken ilk soru, bu tanımlar yığını içerisinde hangi siyasal kültür tanımını temel alması gerektiğine yöneliktir.

Peki, bu sorun nasıl aşılabilir? Bu soruyu cevaplamak hiç de kolay görünmüyor. Bir defa siyasal kültürü tanımlama süreci, The Civic Culture çalışmasının başlattığı, ancak henüz sonlanmamış bir süreç. Sağlam temellere dayandırılmış bir siyasal kültür tanımının ortaya çıma ihtimali her zaman var. Bu olasılık haricinde bu soruya cevaben iki öneri göze çarpıyor. Bu önerilerden ilki, The Civic Culture geleneğini tüm eleştirilere rağmen devam ettirmek, çünkü Gabriel’e göre (1994:29), The Civic Culture, siyasal kültür araștırmaları içerisinde teori ve metot bakımından güçlü temellere sahip ve bu yüzden diğer yaklaşımlar karşısında onu terk etmek için bir sebep bulunmuyor. İkinci öneri ise, siyasal kültür kavramını, belirsiz bir yapıya sahip olmasından dolayı tamamen terk etmeye yönelik (Lehman, 1972:369). 


\section{Kaynakça}

Almond, G. A. (1987) "Politische Kultur-Forschung- Rückblick und Ausblick", in Berg-Schlosser, D. and Schissler, J. (1987) Politische Kultur in Deutschland; Bilanz und Perspektiven der Forschung, Opladen: Wetsdeutscher Verlag, s. 27-39.

Almond, G. A. (1989) "The Intellectual History of the Civic Culture Concept”, in Almond, G. A. and Verba, S. (Ed.) (1989) Civic Culture Revisited, California; First Sage Printing, s. 1-37.

Almond, G. A., Verba, S. (1963) The Civic Culture; Political Attitudes and Democracy in Five Nations, Princeton (New Jersey): Princeton University Press.

Benedict, R. (1960) Patterns of Culture, Eighteenth Printing, England: Routledge \& Kegan Paul Ltd.

Berezin, M. (1997) “Politics and Culture: A Less Fissured Terrain”, Annu. Rev. Sociol. 23(1997): 361-383.

Berger, P. L., Kellner, H. (1965) "Die Ehe und die Konstruktion der Wirklichkeit; Eine Abhandlung zur Mikrosoziologie des Wissens”, Soziale Welt, 16. Jahrg. H. 3 (1965): 220-235.

Berger, P. L., Luckmann, T. (1990) Die gesellschaftliche Konstruktion der Wirklichkeit; eine Theorie der Wissenssoziologie, unveränd. Abdr. der 5. Aufl., Frankfurt am Main: Fischer-Taschenbuch-Verlag.

Bergesen, A. J. (1978) "Rituals, Symbols, and Society-Explicating the Mechanisms of the Moral Order", American Journal of Sociology, Vol. 83, No. 4 (Jan., 1978): 1012-1021.

Bierstedt, R. (1938) “The Means-End Schema in Socioloigical Theory”, American Sociological Review, Vol. 3, No. 5 (Oct., 1938): 665-671.

Brady, H. E., Sniderman, P. M. (1985) "Attitude Attribution; A Group Basis for Political Reasoning”, The American Political Science Review, Vol. 79, No. 4 (1985): 1061-1078.

Chapin, F. S. (1934) "Latent Culture Patterns of the Unseen World of Social Reality", American Journal of Sociology, Vol. 40, No. 1 (1934): 61-68.

Chilton, S. (1988) “Defining Political Culture”, The Western Political Quarterly, Vol. 41, No. 3. (Sep., 1988): 419-445.

Cobb, R. W. (1973) “The Belief-Systems Perspective; An Assessment of a Framework”, The Journal of Politics, Vol. 35, No. 1 (1973): 121-153.

Cohen, A. (1979) "Political Symbolism”, Annual Review of Anthropology, Vol. 8(1979): 87-113.

Dake, K., Thompson, M. (1999) "Making ends meet, in the household and on the planet", GeoJournal, 47:3 (1999): 417-424.

Dittmer, L. (1977) "Political Culture and Political Symbolism; Toward a Theoretical Synthesis", World Politics, Vol. 29, No. 4 (1977): 552-583.

Dittmer, L. (1980) “The Radical Critique of Political Interest, 1966-1978”, Modern China, Vol. 6, No. 4 (Oct., 1980): 363-396.

Douglas, M. (1972) “Deciphering a Meal”, Daedalus, Vol. 101, No. 1, Myth, Symbol, and Culture (Winter, 1972): 61-81.

Douglas, M. (1989) “The Background of the Grid Dimension; A Comment”, Sociological Analysis, Vol. 50, No. 2, Thematic Issue: A Durkheimian Miscellany (Summer, 1989): 171-176.

Douglas, M. (1999) “Four cultures; the evolution of a parsimonious model”, GeoJournal, 47: 3 (1999): 411415.

Durkheim, E. (1982) The Rules of Sociological Method, New York: The Free Press.

Dyke, V. V. (1962) "Values and Interests", The American Political Science Review, Vol. 56, No. 3 (Sep., 1962): 567-576.

Edelman, M. (1960) "Symbols and Political Quiescence", The American Political Science Review, Vol. 54, No. 3 (Sep., 1960): 695-704. 
Elazar, D. J. (1994) “The American Mosaic”, (1994), sayfa 9'dan aktaran Mamadouh, V. D. (1997) “Political culture; a typology grounded on Cultural Theory", GeoJournal 43:1 (1997): 17-25. Burada s. 18.

Elkins, D. J., Simeon, R. E. B. (1979) “A cause in search of its effect, or what does political culture explain?”, Comparative Politics, Vol. 11. No 2 (1979): 120-147.

Formisano, R. P. (2001) “The Concept of Political Culture”, Journal of Interdisciplinary History, xxxi:3 (Winter, 2001): 393-426.

Gabriel, O. W. (1994) "Politische Kultur aus der Sicht der empirischen Sozialforschung", Niedermayer, O. and Beyme, K. von (Hrsg.) (1994) Politische Kultur in Ost- und Westdeutschland, Berlin: Akademie Verlag, s. 22-42.

Geertz, C. (1972) “Deep Play; Notes on the Balinese Cockfight”, Daedalus, Vol. 101, No. 1, Myth, Symbol, and Culture (Winter, 1972): 1-37.

Gendzel, G. (1997) "Review: Political Culture: Genealogy of a Concept", The Journal of Interdisciplinary History, Vol. 28, No. 2 (Autumn, 1997): 225-250.

Halbwachs, M. (1939) "Individual Consciousness and Collective Mind", American Journal of Sociology, Vol. 44, No. 6 (1939): 812-822.

Hendriks, F. (1999) “The post-industrialising city; political perspectives and cultural biases”, GeoJournal, 47: 3 (1999): 425-432.

Inglehart, R. (1971) “The Silent Revolution in Europe; Intergenerational Change in Post-Industrial Societies”, The American Political Science Review, Vol. 65, No. 4 (1971): 991-1017.

Inglehart, R. (1988) "Renaissance of Political culture", The American Political Science Review, Vol. 82, No. 4 (1988): 1203-1230.

Inglehart, R., Granato, J., Leblang, D. (1996a) "Cultural Values, Stable Democracy, and Economic Development: A Reply”, American Journal of Political Science, Vol. 40 No. 3: 680-696.

Inglehart, R., Granato, J., Leblang, D. (1996b) “The Effect of Cultural Values on Economic Development: Theory, Hypothesis and some Empirical Tests”, American Journal of Political Science, Vol. 40 No. 3: 607-631.

Jaeger, G., Selznick, P. (1964) “A Normative Theory of Culture”, American Sociological Review, Vol. 29, No. 5 (Oct., 1964): 653-669.

Jowitt, K. (1974) "An Organizational Approach to the Study of Political Culture in Marxist-Leninist Systems", The American Political Science Review, Vol. 68, No. 3 (1974): 1171-1191.

Kluckhohn, C., Hoebel, E. A. (1943) "Covert Culture and Administrative Problems", American Anthropologist, New Series, Vol. 45, No. 2, Centenary of the American Ethnological Society (1943): 213-229.

Kroeber, A. L., Kluckhohn, C. (1952) Culture; A Critical Review of Concepts and Definitions, Cambridge, Massachusetts. Published by the Museum 1952, Papers of the Peabody Museum of American Archaeology and Ethnology, Harvard University Vol. XLVII-ND. 1.

Laitin, D. D. (1995) “The Civic Culture at 30”, The American Political Science Review, Vol. 89 No.1 (1995): 168-173.

Laitin, D. D., Wildavsky, A. (1988) "Political Culture and Political Preferences", The American Political Science Review, Vol. 82, No. 2 (Jun., 1988): 589-597.

Latham, E. (1952) “The Group Basis of Politics; Notes for a Theory”, The American Political Science Review, Vol. 46. No. 2: 376-397.

Lehman, E. W. (1972) “On the Concept of Political Culture: A Theoretical Reassessment”, Social Forces, Vol. 50, No. 3 (Mar., 1972): 361-370.

Lijphart, A. (1989) “The Structure of Inference”, in Almond, G. A. and Verba, S. (Ed.) (1989) Civic Culture Revisited, California; First Sage Printing, 1989, s. 37-57. 
Lockhart, C. (2001) "Political Culture, Patterns of American Political Development, and Distinctive Rationalities", The Review of Politics, Vol. 63, No. 3 (Summer, 2001): 517-548.

Mamadouh, V. D. (1997) “Political Culture; A Typology Grounded on Cultural Theory”, GeoJournal 43:1 (1997): 17-25.

Mamadouh, V. D. (1999a) “Grid-Group Cultural Theory; An Introduction”, GeoJournal, 47:3 (1999): 395409.

Mamadouh, V. D. (1999b) "A Political-Cultural Map of Europe; Family Structures and the Origins of Differences between National Political Cultures in the European Union", GeoJournal, 47:3 (1999): 477-486.

Matjan, G. (1998) Auseinandersetzung mit der Vielfalt; Politische Kultur und Lebensstile in pluralistischen Gesellschaften, Frankfurt am Main: Campus Verlag.

Morgan, D. R., Watson, S. S. (1991) "Political Culture, Political System Characteristics, and Public Policies among the American States”, Publius, Vol. 21, No. 2, State Political Subcultures: Further Research (Spring, 1991): 31-48.

Muller, E. N., Seligson, M. A. (1994) “Civic Culture and Democracy: The Question of Causal Relationships", The American Political Science Review, Vol. 88, No. 3 (Sep., 1994): 635-652.

Newcomb, T. M. (1942) "Community Roles in Attitude Formation", American Sociological Review, Vol. 7, No. 5 (1942): 621-630.

Opielka, M. (2006) “Politische Kultur -Zur Aktualität eines Theorieprogramms”, Sİ:SO Siegen:Sozial, JG 11: 2 (2006): 45-50.

Pateman, C. (1971) "Political Culture, Political Structure and Political Change", British Journal of Political Science, Vol. 1, No. 3 (1971): 291-305.

Patrick, G. M. (1984) "Political Culture", in Sartori, Giovanni (Ed.) (1984) Social Science Concepts: A Systematic Analysis, Beverly Hills'den aktaran Sarıbay, Ali Yaşar (1992) Siyasal Sosyolojisi, Ankara: Gündoğan Yayınları, s. 67.

Putnam, R. (1966) "Political Attitudes and the Local Community", The American Political Science Review, Vol. 60, No. 3 (1966): 640-654.

Putnam, R. (1971) "Studying Elite Political Culture: The Case of Ideology", The American Political Science Review, Vol. 65, No. 3 (1971): 651-681.

Putnam, R., Leonardi, R., Nanetti, R. Y. (1993) Making Democracy Work: Civic Traditions in Modern Italy, Princeton: Princeton University Press.

Pye, L. W. (1978) "Communications and Chinese Political Culture", Asian Survey, Vol. 18, No. 3 (1978): 221-246.

Pye, L. W. (1991a) “Political Culture Revisited”, Political Psychology, Vol. 12, No. 3 (1991): 487-508.

Pye, L. W. (1991b) “The State and the Individual: An Overview Interpretation”, The China Quarterly, No. 127, Special Issue: The Individual and State in China (1991): 443-466.

Pye, L. W. (1997) "Introduction; The Elusive Concept of Culture and the Vivid Reality of Personality", Political Psychology, Vol. 18, No. 2, Special Issue: Culture and Cross-Cultural Dimensions of Political Psychology (1997): 241-254.

Rohe, K. (1987) "Politische Kultur und kulturelle Aspekt von politischer Wirklichkeit- Konzeptionelle und typologische Überlegungen zu Gegenstand und Fragestellung Politischer Kultur-Forschung", in Berg-Schlosser, D. and Schissler, J. (Hrsg.) (1987) Politische Kultur in Deutschland: Bilanz und Perspektiven der Forschung, Politische Vierteljahresschrift, Sonderheft 18, s. 39-49.

Rohe, K. (1990) "Politische Kultur und ihre Analyse; Probleme und Perspektiven der politischen Kulturforschung", Historische Zeitschrift, Band 250: 321- 346.

Rohe, K. (1994a) "Politische Kultur; Zum Verständnis eines theoretischen Konzepts”, in Niedermayer, O. 
and Beyme, K. von (Hrsg.) (1994) Politische Kultur in Ost- und Westdeutschland, Berlin: Akademie Verlag, s. 1-21.

Rohe, K. (1994b) Politik; Begriffe und Wirklichkeiten, Eine Einführung in das politische Denken, 2. Aufl., Stuttgart: Kohlhammer.

Scheuch, E. K. (1993a) “Theoretical Implications of Comparative Survey Research; Why the Wheel of CrossCultural Methodology Keeps on Being Reinvented”, Historical Social Research, Vol. 18, No. 2 (66): 172-195.

Scheuch, E. K. (1993b) “The Cross-Cultural Use of Sample Surveys: Problems of Comparability”, Historical Social Research, Vol. 18, No. 2 (66): 104-138.

Scheuch, E. K. (2006) "Die wechselnde Datenbasis der Soziologie; zur Interaktion zwischen Theorie und Empirie”, Historische Sozialforschung, No. 18, (2006): 24-46, Reprint from: HSF Vol. 2 (1977): 5-41.

Schütz, A., Parsons, T. (1977) Zur Theorie sozialen Handelns; Ein Briefwechsel, Walter M. Sprondel (Hrsg.), Frankfurt am Main: Suhrkamp.

Schwelling, B. (2001) "Politische Kulturforschung als kultureller Blick auf das Politische; Überlegungen zu einer Neuorientierung der Politischen Kulturforschung nach dem Cultural Turn”, Zeitschrift für Politikwissenschaft 11. Jg. Heft 2 (2001): 601-629.

Sharkansky, I. (1969) “The Utility of Elazar's Political Culture; A Research Note”, Polity, Vol. 2, No. 1 (Autumn, 1969): 66-83.

Somers, M. R. (1992) “The political culture concept: The empirical power of conceptual transformation", CSST working Paper \#88, https://deepblue.lib.umich.edu/bitstream/handle/2027.42/51252/486. pdf? sequence=1\&isAllowed $=y(15.04 .2016)$.

Spickard, J. V. (1989) “A Guide to Mary Douglas's Three Versions of Grid-Group Theory”, Sociological Analysis, Vol. 50, No. 2, Thematic Issue: A Durkheimian Miscellany (Summer, 1989):151-170.

Swedlow, B. (2002) “Toward cultural analysis in policy analysis; Picking up where Aaron Wildavsky left off”, Journal of Comparative Policy Analysis: Research and Practice, 4:3:267-285.

Swedlow, B. (2011) "A Cultural Theory of Politics", PS: Political Science \& Politics, Volume 44, Issue 04 (2011):703710.

Swidler, A. (1986) “Culture in Action: Symbols and Strategies”, American Sociological Review, Vol. 51, No. 2 (1986):273-286.

Tucker, R. C. (1973) “Culture, Political Culture, and Communist Society”, Political Science Quarterly, Vol. 88, No. 2 (1973):173-190.

Walzer, M. (1967) “On the Role of Symbolism in Political Thought”, Political Science Quarterly, Vol. 82, No. 2 (1967):191-204.

Wedeen, L. (2002) “Conceptualizing Culture: Possibilities for Political Science”, The American Political Science Review, Vol. 96, No. 4 (2002):713-728.

Welch, S. (1993) The Concept of Political Culture, New York: St. Martin's Press.

Verba, S. (1965) "Comparative Political Culture”, in Pye, L. W. and Verba, S. (Ed.) (1965) Political Culture and Political Development, New Jersey: Princeton University Press, s. 512-561.

Verba, S. (1993) "The uses of survey research in the study of comparative politics: issues and strategies", Historical Social Research 18:2 (1993):55-103.

White, L. A. (1940) “The Symbol; The Origin and Basis of Human Behavior”, Philosophy of Science, Vol. 7, No. 4 (1940):451-463.

White, L. A. (1947) "Culturological vs. Psychological Interpretations of Human Behavior", American Sociological Review, Vol. 12, No. 6 (1947):686-698. 
Wildavsky, A. (1987) "Choosing Preferences by Constructing Institutions: A Cultural Theory of Preference Formation", The American Political Science Review 81 (1) (1987):3-22.

Wildavsky, A. (1989) "If Institutions Have Consequences, Why Don't We Hear About Them From Moral Philosophers?", The American Political Science Review, Vol. 83, No. 4 (Dec., 1989):1343-1351.

Wildavsky, A., Dake, K. (1990) “Theories of Risk Perception; Who Fears What and Why?”, Daedalus, Vol. 119 No. 4:41-60.

Wilson, R. W. (2000) “The Many Voices of Political Culture; Assessing Different Approaches”, World Politics, Vol. 52, No. 2 (2000):246-273. 